\title{
ANALISIS VEGETASI DI BLOK INTI HUTAN LINDUNG REGISTER 21 KESATUAN PENGELOLAAN HUTAN XI KABUPATEN PESAWARAN
}

\section{Vegetation Analysis on The Core Block of Register 21 Protected Forest of Forest Management Unit (KPH ) XI Pesawaran District}

\author{
Tedy Rendra ${ }^{1^{*}}$, Duryat ${ }^{1}$, dan Afif Bintoro ${ }^{1}$ \\ 1 Jurusan Kehutanan, Fakultas Pertanian Universitas Lampung \\ JI. Prof. Dr. Soemantri Brojonegoro No. 1 Bandar Lampung 35145 \\ *e-mail: dyrendra@gmail.com
}

\begin{abstract}
ABSTRAK
Sumber daya hutan harus terjaga kelestariannya salah satunya adalah hutan lindung. Hutan lindung mempunyai fungsi mengatur tata air. Vegetasi tanaman pada hutan lindung sangat penting untuk mempertahankan fungsinya. Penelitian ini bertujuan mengetahui komposisi vegetasi blok inti hutan lindung. Penelitian dilakukan pada blok inti hutan lindung register 21 Kesatuan Pengelolaan Hutan (KPH) XI Pesawaran pada bulan Agustus - Oktober 2017. Pengambilan sampel dilakukan menggunakan metode continuous sampling with random start dengan jumlah plot sebanyak 45 buah. Analisis dilakukan menggunakan Indeks Nilai Penting (INP). Hasil analisis menunjukkan terdapat 40 jenis tanaman yang terdiri atas 21 famili, didominasi oleh Theobroma cacao dengan INP sebesar $130 \%$.
\end{abstract}

Kata Kunci : Blok Inti, Hutan Lindung, Komposisi, Struktur.

\begin{abstract}
Forest resources should be maintained its sustainability is one of the proctected forest. The protected forest has function of regulating water.Vegetation plants in protected forest are very important to maintain their function. This study aims to know composition of vegetation core block of protected forest. The research carried out on core block of register 21 protected forest of Forest Management Unit (KPH )XI Pesawaran in August October 2017. The sample performed using continuous sampling with random start method with the number of 45 objects. Analysis carried out using Important Value Index (INP). The result of analysis showed there were 40 species of plants which consists of 21 family, dominated by Theobroma cacao with INP of $130 \%$.
\end{abstract}

Keywords: Composition, Core Block, Protected Forest, Structure 


\section{PENDAHULUAN}

Sumberdaya alam khususnya sumberdaya hutan merupakan penyangga sistem kehidupan yang perlu dijaga keberadaannya (Cahyanto et al. 2014). Sumberdaya hutan terdiri dari berbagai macam ekosistem yang tidak dapat dipisahkan satu sama lainnya.Ekosistem hutan tersebut membentuk sistem tajuk yang tinggi sehingga mampu menahan laju erosi (Nagel, 2011).

Berdasarkan fungsinya dalam peraturan perundangundangan yaitu Undang-Undang No. 41 tahun 1999 hutan dibagikan ke dalam 3 fungsi yaitu hutan lindung, hutan konservasi, dan hutan produksi. Adapun ekosistem hutan yang mampu menahan laju erosi adalah hutan lindung. Hutan lindung didefiniskan sebagai kawasan hutan yang mempunyai fungsi pokok sebagai perlindungan sistem penyangga kehidupan untuk mengatur tata air, mencegah banjir, mengendalikan erosi, mencegah intrusi air laut dan memelihara kesuburan tanah (UU No. 41 tahun 1999). Jenis tanaman yang mampu menjalankan fungsi tersebut sangat dibutuhkan. Zulkarnain (2013) menyatakan bahwa jenis dan ukuran pohon adalah faktor yang menentukan dalam kemampuan hutan mengendalikan curah hujan. Kawasan Hutan Lindung Register 21 merupakan salah satu kawasan hutan lindung yang dikelola oleh Kesatuan Pengelolaan Hutan (KPH) XI Pesawaran yang terdapat di Provinsi Lampung. Wilayah hutan yang dikelola oleh $\mathrm{KPH}$ tersebut sebagian besar ditutupi oleh pertanian lahan kering hingga mencapai diatas 70\% (Mustari, 2014).

Berdasarkan hal tersebut, fungsi hutan sebagai pengatur tata air belum dapat terlaksana. Jenis tanaman yang dapat mengatur sistem tata air diperlukan pada kawasan hutan lindung KPH XI Pesawaran. Fungsi hutan lindung sangat ditentukan oleh vegetasi yang menutupi kawasan tersebut (Efendi et al., 2016).Analisis vegetasi merupakan petak ukur $10 \mathrm{~m} \times 10 \mathrm{~m}$ untuk pengamatan poles (tiang), petak ukur $5 \mathrm{~m} \times 5 \mathrm{~m}$ untuk pengamatan salah satu cara yang dapat digunakan untuk mengetahui jenis tanaman di Hutan Lindung Register $21 \mathrm{KPH}$ XI Pesawaran. Tujuan penelitian ini adalah untuk mengetahui komposisi dan struktur vegetasi yang terdapat pada blok inti hutan lindung register $21 \mathrm{KPH}$ XI Pesawaran.

\section{Bahan dan Metode}

Penelitian ini telah dilaksanakan di wilayah Blok Inti Hutan Lindung Register $21 \mathrm{KPH}$ XI Pesawaran, pada bulan Agustus sampai dengan bulan Oktober 2017. Alat yang digunakan berupa kamera digital Nikon 16 megapixel, tally sheet, rol meter, tali rafia, golok, GPS dan kunci determinasi tumbuhan. Bahan yang digunakan yaitu tegakan hutan yang terdapat pada blokinti register $21 \mathrm{KPH}$ XI Pesawaran.

Areal blok inti register 21 memiliki luasan sebesar 720,36 ha, dengan intensitas sampling (IS) sebesar $2,5 \%$, jumlah petak sampel dalam penelitian ini sebanyak 45 plot. Metode sampling yang digunakan adalah stratifikasi sampling yang didasarkan pada 2 kelas ketinggian tempat yaitu zona hutan hujan bawah (0-1.000 mdpl) dan zona hutan hujan tengah (1.000-3.300 mdpl) sehingga memungkinkan jenis vegetasi yang tumbuh berbeda. Sampling diambil secara proporsional berdasarkan luas masingmasing kelas ketinggian tempat, maka didapatkan jumlah pembagian petak sebanyak 33 petak ukur pada zona hutan hujan bawah dan 12 petak ukur pada zona hutan hujan tengah.

Pelaksanaan penelitian dilakukan meliputi, (1) persiapan analisis vegetasi dan jenis potensi pohon lokal untuk fitoremediasi yang dilakukan pada blok inti hutan lindung register 21 Kabupaten Pesawaran. Jalur diletakkan secara continuous sampling with random start dengan lebar jalur $20 \mathrm{~m}$. (2) Jarak antar petak pengamatan sepanjang $300 \mathrm{~m}$ dan jarak antar jalur pengamatan $400 \mathrm{~m}$, adapun petak ukur berukuran $20 \mathrm{~m} \times 20 \mathrm{~m}$ untuk pengamatan pohon, sapling, dan petak ukuran $2 \mathrm{~m} \times 2 \mathrm{~m}$ untuk pengamatan seedling atau tumbuhan bawah. 
59 / Rendra T, Duryat, dan Bintoro A.

Pengamatan variabel terhadap individu berupa jenis pohon, jumlah individu tiap jenis dalam petak serta diameter untuk tingkat pancang, tiang dan pohon.

Data yang diperoleh akan dianalisis secara kuantitatif dengan perhitungan indeks nilai penting (INP) dari masing-masing jenis yang ditemukan. Pada tingkat semai INP yang dihitung adalah kerapatan relatif $(K R)$ dan frekuensi relatif $(F R)$, sedangkan pada

tingkat pancang, tiang dan pohon INP yang dihitung adalah kerapatan relatif, frekuensi relatif, dan dominasi relatif (CR) (Indriyanto, 2008).

\section{Hasil dan Pembahasan}

Hasil analisis vegetasi terhadap wilayah hutan lindung register $21 \mathrm{KPH}$ Pesawaran pada blok inti adalah indeks nilai penting (INP). INP didapatkan dari kerapatan relatif $(K R)$ ditambah frekuensi relatif (FR) dan dominansi relatif (CR) pada fase pancang,

Kerapatan-i $=\frac{(\Sigma \text { individu } \mathrm{ke}-\mathrm{i})}{\text { luas petak } u k u r}$

Kerapatan Relatif-i $=\left(\frac{\text { Kerapatan spesies } k e-i}{\text { Ekerapatan spesies }}\right) \times 100 \%$

Frekuensi-i $\quad=\left(\frac{\sum \text { petak ditemukan spesies ke-i }}{\Sigma \text { petak contoh }}\right)$

Frekuensi Relatif-i $=\left(\frac{\text { frekuensi spesies ke-i }}{\Sigma \text { frekuensi }}\right) \times 100 \%$

Dominansi-i $=\left(\frac{\text { luas bidang dasar }}{\text { luas petak contoh }}\right)$

Dominansi Relatif-i $=\left(\frac{\text { Dominansi spesies } k e-i}{\Sigma \text { Dominansi }}\right) \times 100 \%$ Indeks Nilai Penting $-\mathrm{i}=\mathrm{KR}-\mathrm{i}+\mathrm{FR}-\mathrm{i}+\mathrm{CR}-\mathrm{i}$

tiang dan pohon. Fase semai INP diperoleh dari kerapatan relatif ditambah frekuensi relatif. Nilai INP fase semai, fase pancang, fase tiang, dan fase pohon disajikan pada Tabel 1.

Tabel 1. Indeks nilai penting tumbuhan pada fase semai, pancang, tiang dan pohon yang terdapat pada blok No. inti register $21 \mathrm{KPH}$ Pesawaran.

\begin{tabular}{|c|c|c|c|c|c|}
\hline \multirow[t]{2}{*}{ No. } & \multirow[t]{2}{*}{ Nama Lokal } & \multicolumn{4}{|c|}{ INP (\%) } \\
\hline & & Semai & Pancang & Tiang & Pohon \\
\hline (1) & $(2)$ & (3) & $(4)$ & (5) & (6) \\
\hline 1 & Alang - Alang (Imperata cylindrical) & 3 & 0 & 0 & 0 \\
\hline 2 & Awar-awar (Ficus septica) & 0 & 6 & 0 & 4 \\
\hline 3 & Bandotan (Ageratum conyzoide) & 24 & 0 & 0 & 0 \\
\hline 4 & Cempaka (Michelia champaca) & 0 & 3 & 33 & 29 \\
\hline 5 & Cengkeh (Syzygium aromaticum) & 0 & 40 & 0 & 0 \\
\hline 6 & Durian (Durio zibethinus) & 2 & 25 & 61 & 48 \\
\hline 7 & Jabon (Anthocephalus cadamba) & 0 & 0 & 34 & 8 \\
\hline 8 & Jambu Biji (Psidium guajava) & 1 & 7 & 0 & 0 \\
\hline 9 & Jati (Tectona grandis) & 0 & 0 & 0 & 4 \\
\hline 10 & Jengkol (Archidendroin pauciflorum) & 0 & 0 & 0 & 4 \\
\hline 11 & Kakao (Theobroma cacao) & 1 & 130 & 0 & 0 \\
\hline 12 & Kaliandra (Calliandra calothyrsus) & 12 & 8 & 0 & 0 \\
\hline 13 & Karet (Hevea brasiliensis) & 0 & 0 & 7 & 5 \\
\hline 14 & Kemiri (Aleurites moluccana) & 0 & 19 & 20 & 43 \\
\hline 15 & Kentangan (Coleus atropurpureus) & 39 & 0 & 0 & 0 \\
\hline 16 & Kirinyuh (Chromolaena odorata) & 21 & 0 & 0 & 0 \\
\hline 17 & Kopi (Coffea canephora) & 0 & 43 & 0 & 0 \\
\hline 18 & Lengkuas (Alpina galanga) & 1 & 0 & 0 & 0 \\
\hline 19 & Mahoni (Swietenia macrophylla) & 0 & 9 & 0 & 12 \\
\hline 20 & Mangga (Mangifera Indica) & 0 & 0 & 26 & 6 \\
\hline 21 & Medang (Litsea firma) & 0 & 0 & 0 & 5 \\
\hline
\end{tabular}




\begin{tabular}{|c|c|c|c|c|c|}
\hline 22 & Melinjo (Gnetum gnemon) & 0 & 10 & 43 & 23 \\
\hline 23 & Meniran (Phyllanthus niruri) & 5 & 0 & 0 & 0 \\
\hline 24 & Mimosa (Mimosa pigra) & 8 & 0 & 0 & 0 \\
\hline 25 & Nanas Merah (Ananas bracteatus) & 1 & 0 & 0 & 0 \\
\hline 26 & Pakis Kelabang (Nephrolepis exeltata) & 13 & 0 & 0 & 0 \\
\hline 27 & Paku Pedang (Nephrolepis biserrata) & 11 & 0 & 0 & 0 \\
\hline 28 & Petai (Parkia speciosa) & 1 & 0 & 55 & 29 \\
\hline 29 & Randu (Ceiba pentandra) & 0 & 0 & 0 & 33 \\
\hline 30 & Rane (Selaginella martensii) & 9 & 0 & 0 & 0 \\
\hline 31 & Rija Rija (Scleria sumatrensis) & 1 & 0 & 0 & 0 \\
\hline 32 & Rumput Grinting (Cynodon dactylon) & 9 & 0 & 0 & 0 \\
\hline 33 & Rumput Teki (Cyperus rotundus) & 9 & 0 & 0 & 0 \\
\hline 34 & Semanggi Gunung (Hydrocotyle) & 6 & 0 & 0 & 0 \\
\hline 35 & Sengon (Paraserianthes falcataria) & 2 & 0 & 21 & 20 \\
\hline 36 & Sidaguri (Sida rhombifolia) & 8 & 0 & 0 & 0 \\
\hline 37 & Sonokeling (Dalbergia latifolia) & 0 & 0 & 0 & 17 \\
\hline 38 & Tapak Liman (Elephantopus scaber) & 12 & 0 & 0 & 0 \\
\hline 39 & Takokak (Solanum torvum) & 4 & 0 & 0 & 0 \\
\hline 40 & Wareng (Gmelina arborea) & 0 & 0 & 0 & 10 \\
\hline \multicolumn{2}{|r|}{ Total } & 200 & 300 & 300 & 300 \\
\hline
\end{tabular}

Tabel 1. menunjukkan INP pada setiap jenis tanaman pada berbagai fase, yaitu fase semai, fase pancang, fase tiang, dan fase pohon. INP tertinggi pada fase semai adalah INP pada tanaman kentangan (Coleus atropurpureus), pada fase pancang adalah tanaman kakao (Theobroma cacao), pada fase tiang dan pada fase pohon adalah tanaman durian (Durio zibethinus). Tanaman durian memiliki INP yang tinggi pada fase tiang dan pohon, hal ini menunjukkan bawah durian memiliki peranan yang cukup besar pada blok inti register $21 \mathrm{KPH}$ XI Pesawaran. Nilai INP yang tinggi dari suatu spesies menunjukkan tingginya peranan spesies tersebut dalam komunitas tumbuhan (Kainde, 2011).
Hasil analisis vegetasi terhadap fase semai, fase pancang, fase tiang, dan fase pohon menunjukkan jumlah dan spesies yang berbeda. Pada fase semai diperoleh sebanyak 24 spesies tanaman, pada fase pancang diperoleh sebanyak 11 spesies, fase tiang diperoleh sebanyak 9 spesies, dan pada fase pohon diperoleh sebanyak 17 spesies. Semua spesies tersebut, dianalisis variabel pendukungnya untuk mendapatkan INP pada setiap fase. Adapun spesies-spesies tersebut pada setiap fase dapat dilihat pada Tabel 2, Tabel 3, Tabel 4, dan Tabel 5

Tabel 2. Kerapatan, frekuensi, dan indeks nilai penting dari setiap jenis spesies pada fase semai yang terdapat pada blok inti register $21 \mathrm{KPH}$ XI Pesawaran.

\begin{tabular}{|r|l|r|r|r|r|r|}
\hline No. & \multicolumn{1}{|c|}{ Jenis } & K-i & Kr-i(\%) & \multicolumn{1}{|c|}{ F-i } & Fr-i(\%) & INP-i (\%) \\
\hline $\mathbf{1}$ & Alang - Alang & 444,44 & 1 & 0,07 & 2 & 3 \\
\hline $\mathbf{2}$ & Bandotan & $\mathbf{4 8 8 8 , 8 9}$ & $\mathbf{1 1}$ & $\mathbf{0 , 5 1}$ & $\mathbf{1 2}$ & $\mathbf{2 4}$ \\
\hline $\mathbf{3}$ & Durian & 222,22 & 1 & 0,04 & 1 & 2 \\
\hline $\mathbf{4}$ & Jambu Biji & 55,56 & 0 & 0,02 & 1 & 1 \\
\hline $\mathbf{5}$ & Kakao & 55,56 & 0 & 0,02 & 1 & 1 \\
\hline $\mathbf{6}$ & Kaliandra & 1944,44 & 4 & 0,31 & 7 & 12 \\
\hline $\mathbf{7}$ & Kentangan & $\mathbf{9 8 8 8 , 8 9}$ & $\mathbf{2 3}$ & $\mathbf{0 , 6 7}$ & $\mathbf{1 6}$ & $\mathbf{3 9}$ \\
\hline
\end{tabular}


61 / Rendra T, Duryat, dan Bintoro A.

\begin{tabular}{|c|c|c|c|c|c|c|}
\hline 8 & Kirinyuh & 4111,11 & 9 & 0,47 & 11 & 21 \\
\hline 9 & Lengkuas & 111,11 & 0 & 0,02 & 1 & 1 \\
\hline 10 & Meniran & 1111,11 & 3 & 0,11 & 3 & 5 \\
\hline 11 & Mimosa & 1333,33 & 3 & 0,20 & 5 & 8 \\
\hline 12 & Nanas Merah & 55,56 & 0 & 0,02 & 1 & 1 \\
\hline 13 & Pakis Kelabang & 3055,56 & 7 & 0,24 & 6 & 13 \\
\hline 14 & Paku Pedang & 2388,89 & 6 & 0,22 & 5 & 11 \\
\hline 15 & Petai & 222,22 & 1 & 0,02 & 1 & 1 \\
\hline 16 & Rane & 2277,78 & 5 & 0,16 & 4 & 9 \\
\hline 17 & Rija Rija & 277,78 & 1 & 0,02 & 1 & 1 \\
\hline 18 & Rumput Grinting & 2111,11 & 5 & 0,16 & 4 & 9 \\
\hline 19 & Rumput Teki & 3166,67 & 7 & 0,09 & 2 & 9 \\
\hline 20 & Semanggi Gunung & 1333,33 & 3 & 0,11 & 3 & 6 \\
\hline 21 & Sengon & 277,78 & 1 & 0,04 & 1 & 2 \\
\hline 22 & Sidaguri & 1277,78 & 3 & 0,20 & 5 & 8 \\
\hline 23 & Tapak Liman & 2166,67 & 5 & 0,31 & 7 & 12 \\
\hline 24 & Takokak & 500,00 & 1 & 0,11 & 3 & 4 \\
\hline & Total & 43277,78 & 100 & 4,16 & 100 & 200 \\
\hline
\end{tabular}

Tabel 2. menunjukkan bahwa terdapat 24 spesies pada fase semai. Spesies kentangan (Coleus atropurpureus) memiliki INP tertinggi sebesar 39\% dengan variabel kerapatan relatif $23 \%$ atau 9889 individu/hektar dan frekuensi relatif sebesar $16 \%$ atau memiliki peluang sebesar 0,67 untuk ditemukan. Tanaman tertinggi kedua adalah bandotan (Ageratum conyzoide) dengan INP sebesar $24 \%$ lalu tanaman kirinyuh (Chromolaena odorata).

Tabel 3. Kerapatan, frekuensi, dominansi dan indeks nilai penting dari setiap jenis spesies pada fase pancang yang terdapat pada blok register $21 \mathrm{KPH}$ XI Pesawaran.

\begin{tabular}{|l|l|r|r|r|r|r|r|r|}
\hline No & \multicolumn{1}{|c|}{ Jenis } & K-i & Kr-i(\%) & F-i & Fr-i(\%) & C-i & Cr-i(\%) & INP-i (\%) \\
\hline $\mathbf{1}$ & Awar & 35,56 & 3 & 0,04 & 3 & 0,07 & 0 & 6 \\
\hline $\mathbf{2}$ & Cempaka & 17,78 & 1 & 0,02 & 1 & 0,04 & 0 & 3 \\
\hline $\mathbf{3}$ & Cengkeh & $\mathbf{2 4 0 , 0 0}$ & $\mathbf{1 7}$ & $\mathbf{0 , 2 4}$ & $\mathbf{1 6}$ & $\mathbf{1 , 0 4}$ & $\mathbf{7}$ & $\mathbf{4 0}$ \\
\hline $\mathbf{4}$ & Durian & 115,56 & $\mathbf{8}$ & 0,20 & 13 & 0,54 & 4 & 25 \\
\hline $\mathbf{5}$ & Jambu Biji & 26,67 & 2 & 0,07 & 4 & 0,06 & 0 & 7 \\
\hline $\mathbf{6}$ & Kakao & $\mathbf{4 5 3 , 3 3}$ & $\mathbf{3 3}$ & $\mathbf{0 , 4 2}$ & $\mathbf{2 7}$ & $\mathbf{1 0 , 2 5}$ & $\mathbf{7 1}$ & $\mathbf{1 3 0}$ \\
\hline $\mathbf{7}$ & Kaliandra & 26,67 & 2 & 0,07 & 4 & 0,26 & 2 & 8 \\
\hline $\mathbf{8}$ & Kemiri & 80,00 & 6 & 0,16 & 10 & 0,48 & 3 & 19 \\
\hline $\mathbf{9}$ & Kopi & $\mathbf{2 9 3 , 3 3}$ & $\mathbf{2 1}$ & $\mathbf{0 , 2 0}$ & $\mathbf{1 3}$ & $\mathbf{1 , 3 2}$ & $\mathbf{9}$ & $\mathbf{4 3}$ \\
\hline $\mathbf{1 0}$ & Mahoni & 44,44 & 3 & 0,07 & 4 & 0,19 & 1 & 9 \\
\hline $\mathbf{1 1}$ & Melinjo & 53,33 & 4 & 0,07 & 4 & 0,26 & 2 & 10 \\
\hline & Total & 1386,67 & 100 & 1,56 & 100 & 14,51 & 100 & 300 \\
\hline
\end{tabular}

Tanaman kakao (Theobroma cacao) memiliki peranan paling besar dalam komposisi vegetasi tingkat pancang dengan INP sebesar 130\%, kerapatan 453 individu/hektar dan peluang ditemukan sebesar 0,42. Kopi (Coffea canephora) dan cengkeh (Syzygium aromaticum) merupakan jenis tanaman selanjutnya yang memiliki peranan dilihat dari INP tanaman tersebut sebesar $43 \%$ dan $40 \%$. Hal ini menunjukkan bahwa adanya pembudidayaan khusus jenis ini oleh masyarakat sekitar atau masyarakat yang tinggal di dalam kawasan hutan lindung. Jika dibandingkan dengan INP jenis lainnya pada Tabel 1, INP jenis kakao adalah INP terbesar. 
Tabel 4. Kerapatan, frekuensi, dominansi dan indeks nilai penting dari setiap jenis spesies pada fase tiang yang terdapat pada blok inti register $21 \mathrm{KPH}$ XI Pesawaran

\begin{tabular}{|l|l|r|r|r|r|r|r|r|}
\hline No & Nama Spesies & K-i & Kr-i(\%) & F-i & Fr-i (\%) & \multicolumn{1}{c|}{ C-i } & Cr-i (\%) & INP-i (\%) \\
\hline $\mathbf{1}$ & Cempaka & 15,56 & 11 & 0,13 & 11 & 0,34 & 11 & 33 \\
\hline $\mathbf{2}$ & Durian & $\mathbf{3 1 , 1 1}$ & $\mathbf{2 2}$ & $\mathbf{0 , 2 2}$ & $\mathbf{1 8}$ & $\mathbf{0 , 6 3}$ & $\mathbf{2 1}$ & $\mathbf{6 1}$ \\
\hline $\mathbf{3}$ & Jabon & 15,56 & 11 & 0,13 & 11 & 0,35 & 12 & 34 \\
\hline $\mathbf{4}$ & Karet & 4,44 & 3 & 0,02 & 2 & 0,06 & 2 & 7 \\
\hline $\mathbf{5}$ & Kemiri & 8,89 & 6 & 0,07 & 5 & 0,23 & 8 & 20 \\
\hline $\mathbf{6}$ & Mangga & 11,11 & 8 & 0,11 & 9 & 0,27 & 9 & 26 \\
\hline $\mathbf{7}$ & Melinjo & $\mathbf{2 0 , 0 0}$ & $\mathbf{1 4}$ & $\mathbf{0 , 1 8}$ & $\mathbf{1 5}$ & $\mathbf{0 , 4 3}$ & $\mathbf{1 5}$ & $\mathbf{4 3}$ \\
\hline $\mathbf{8}$ & Petai & $\mathbf{2 6 , 6 7}$ & $\mathbf{1 9}$ & $\mathbf{0 , 2 7}$ & $\mathbf{2 2}$ & $\mathbf{0 , 4 2}$ & $\mathbf{1 4}$ & $\mathbf{5 5}$ \\
\hline $\mathbf{9}$ & Sengon & 8,89 & 6 & 0,09 & 7 & 0,22 & 7 & 21 \\
\hline & Total & 142,22 & 100 & 1,22 & 100 & 2,95 & 100 & 300 \\
\hline
\end{tabular}

Hasil analisis vegetasi pada fase tiang, diperoleh bahwa tanaman jenis durian (Durio zibethinus), Melinjo (Gnetum gnemo), dan Petai (Parkia speciosa) mendominasi dengan INP masing-masing sebesar $61 \%$, 55\%, dan $43 \%$. Ketiga jenis tanaman ini dapat dimanfaatkan untuk kegiatan ekonomi yaitu dengan mengambil buah atau hasil hutan bukan kayu yang ada pada jenis tanaman tersebut. Sangat memungkinkan bahwa jenis tanaman ini telah dibudidaya oleh masyarakat, telihat pada kerapatan dan frekuensi serta dominasi ketiga tanaman. Tabel 1 juga menunjukkan bahwa terdapat 2 jenis tanaman yaitu durian dan melinjo dengan INP yang cukup untuk beregenerasi ke tahap tiang dan pohon.

Tabel 5. Kerapatan, frekuensi, dominansi dan indeks nilai penting dari setiap jenis spesies pada fase pohon yang terdapat pada blok inti register $21 \mathrm{KPH}$ XI Pesawaran.

\begin{tabular}{|c|c|c|c|c|c|c|c|c|}
\hline No & Jenis & K-i & Kr-i (\%) & $\mathrm{F}-\mathrm{i}$ & FR-i (\%) & C-i & Cr-i (\%) & INP-i (\%) \\
\hline 1 & Awar-Awar & 1,67 & 1 & 0,07 & 2 & 0,13 & 1 & 4 \\
\hline 2 & Cempaka & 16,11 & 10 & 0,31 & 9 & 1,07 & 10 & 29 \\
\hline 3 & Durian & 31,11 & 20 & 0,47 & 14 & 1,58 & 14 & 48 \\
\hline 4 & Jabon & 4,44 & 3 & 0,09 & 3 & 0,33 & 3 & 8 \\
\hline 5 & Jati & 1,67 & 1 & 0,04 & 1 & 0,14 & 1 & 4 \\
\hline 6 & Jengkol & 2,22 & 1 & 0,07 & 2 & 0,09 & 1 & 4 \\
\hline 7 & Kapuk Randu & 13,33 & 8 & 0,38 & 11 & 1,46 & 13 & 33 \\
\hline 8 & Karet & 2,22 & 1 & 0,09 & 3 & 0,08 & 1 & 5 \\
\hline 9 & Kemiri & 21,11 & 13 & 0,44 & 14 & 1,84 & 17 & 43 \\
\hline 10 & Mahoni & 6,11 & 4 & 0,11 & 3 & 0,54 & 5 & 12 \\
\hline 11 & Mangga & 3,33 & 2 & 0,09 & 3 & 0,15 & 1 & 6 \\
\hline 12 & Medang & 2,22 & 1 & 0,04 & 1 & 0,25 & 2 & 5 \\
\hline 13 & Melinjo & 15,56 & 10 & 0,22 & 7 & 0,67 & 6 & 23 \\
\hline 14 & Petai & 14,44 & 9 & 0,40 & 12 & 0,84 & 8 & 29 \\
\hline 15 & Sengon & 10,00 & 6 & 0,20 & 6 & 0,83 & 8 & 20 \\
\hline 16 & Sonokeling & 8,89 & 6 & 0,16 & 5 & 0,78 & 7 & 17 \\
\hline 17 & Wareng & 5,00 & 3 & 0,11 & 3 & 0,34 & 3 & 10 \\
\hline \multicolumn{2}{|c|}{ Total } & 159,44 & 100 & 3,29 & 100 & 11,11 & 100 & 300 \\
\hline
\end{tabular}


63 / Rendra T, Duryat, dan Bintoro A.

Fase pohon terdapat 17 jenis spesies, pada Tabel 5 diketahui bahwa jenis durian memiliki INP paling besar yaitu $48 \%$ dan merupakan jenis yang sama seperti INP fase tiang pada Tabel 7 sebelumnya. Selanjutnya jenis kemiri (Aleurites moluccana) memiliki INP sebesar 43\%. Jenis cempaka (Michelia champaca) dan petai (Parkia speciosa) memiliki INP yang sama besarnya, namun terdapat perbedaan dari variabel kerapatan, frekuensi, dan dominasi jenis tersebut. Jenis cempaka memiliki kerapatan lebih tinggi sebesar 16 individu/hektar jika dibandingkan dengan petai 14 individu/hektar, selain itu cempaka juga memiliki dominasi yang lebih tinggi dari jenis petai yaitu 1,07 dan petai hanya sebesar 0,84 .

Jenis tanaman yang terdapat pada blok inti register $21 \mathrm{KPH}$ XI Pesawaran adalah 40 jenis tanaman. Jenis-jenis tanaman tersebut tersusun dari tumbuhan bawah dan fase semai, fase pancang, fase tiang, serta fase pohon. Jumlah jenis tanaman pada setiap fase dapat dilihat pada Gambar 1

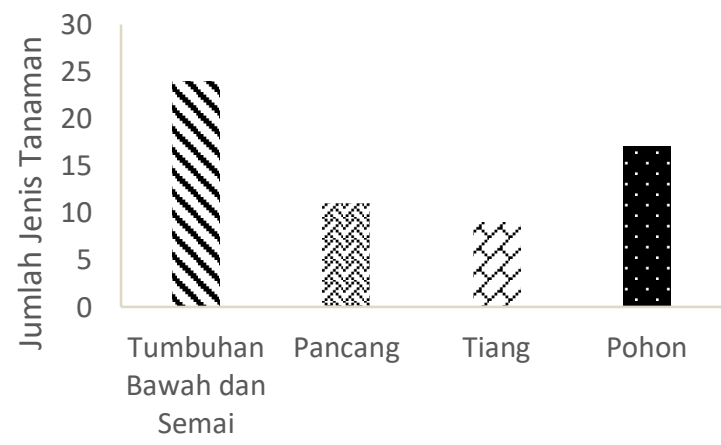

Gambar 1. Jumlah jenis tanaman pada setiap fase pertumbuhan

Hasil analisis menunjukkan jumlah jenis tanaman bawah dan fase semai lebih tinggi jika dibandingkan dengan ketiga fase lainnya. Jumlah tanaman bawah yang lebih tinggi menunjukkan bahwa tanaman bawah mendominasi sehingga mengindikasikan bahwa terdapat banyak ruang terbuka yang memungkinkan cahaya secara langsung mengenai tumbuhan bawah. Cahaya langsung atau sinar matahari yang berlimpah akan meningkatkan pertumbuhan dan perkembangan tumbuhan bawah (Hilwanet al. 2013), sehingga dapat dikatakan bahwa tumbuhan bawah memiliki sifat intoleran.

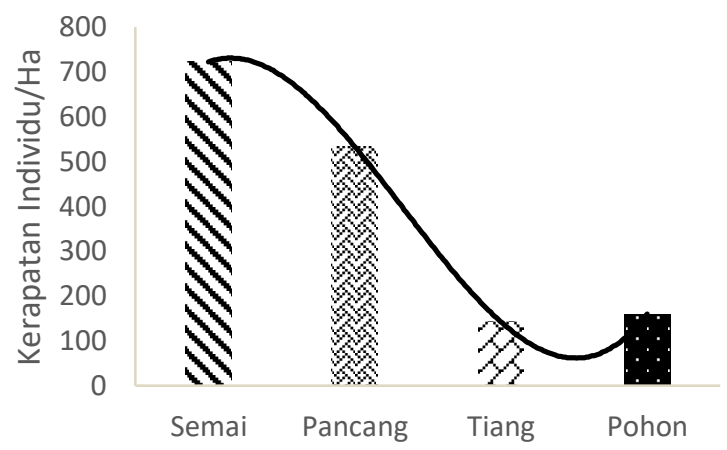

Gambar 2. Struktur vegetasi berdasarkan kerapatan individu/ha pada blok inti hutan lindung register $21 \mathrm{KPH}$ XI Pesawaran.

Kerapatan pada setiap fase pertumbuhan baik pada fase semai, pancang, tiang, dan pohon menunjukkan bertuk kurva $\mathrm{J}$ terbalik seperti yang telihat pada Gambar 2. Hal ini menunjukkan jumlah individu per satuan luas berturut-turut semakin sedikit, namun pada fase pohon jumlah pohon lebih tinggi jika dibandingkan dengan fase tiang. Berdasarkan hal tersebut, regenerasi yang terjadi pada blok inti hutan lindung register $21 \mathrm{KPH}$ XI Pesawaran tidak berjalan dengan baik. Widiyanti \& Kusmana, 2014 menyatakan bahwa struktur horizontal vegetasi hutan membentuk kurva $\mathrm{J}$ terbalik maka suksesi sekunder yang berjalan baik seiring pertambahan waktu.

Jenis tanaman yang memiliki peranan yang tinggi dari 40 jenis tanaman tersebut adalah adalah tanaman kakao (Theobroma cacao) yang memiliki INP tertinggi sebesar $130 \%$ dari fase pancang. Selanjutnya pada fase semai INP tertinggi dimiliki 
oleh jenis tanaman kentangan (Coleus atropurpureus) dengan INP sebesar $61 \%$, pada fase tiang dan pohon adalah tanaman durian (Durio zibethinus) dengan INP sebesar $61 \%$ dan $48 \%$. Tanaman ini merupakan tanaman yang dibudidayakan pada blok inti register $21 \mathrm{KPH}$ XI Pesawaran sehingga memiliki peranan yang besar dalam struktur dan komposisi hutan tersebut.

Fase semai dan tumbuhan bawah terdiri dari 24 jenis tanaman, baik dari tumbuhan bawah atapun tanaman permudaan (fase semai) seperti yang terlihat pada Gambar 1. INP tertinggi dari fase tersebut adalah jenis tanaman kentangan (Coleus atropurpureus) dengan INP sebesar 39\%, selanjutnya jenis tanaman bandotan (Ageratum conyzoide) dengan INP sebesar $24 \%$, dan jenis tanaman kirinyuh (Chromolaena odorata) dengan INP sebesar $21 \%$. Jenis tanaman lainnya memiliki INP yang berkisar antara $1 \%$ - 13\%. Indriyanto(2008) menyatakan bahwa tingginya INP suatu jenis tanaman menunjukkan besar dan atau tidaknya pengaruh suatu jenis tanaman dalam suatu komunitas tumbuhan. Sehingga jenis lainnya dapat dikatakan memiliki pengaruh yang kecil dan tertekan oleh persaingan jenis tanaman yang memiliki INP lebih besar.

Pada fase pancang ditemukan 11 jenis tanaman yang berada pada blok inti register $21 \mathrm{KPH}$ XI Pesawaran. Terdapat 3 jenis tanaman dengan INP yang sangat tinggi yaitu jenis tanaman kakao (Theobroma cacao) dengan INP yang mencapai $130 \%$, selanjutnya jenis tanaman kopi (Coffea canephora) dengan INP 43\%, dan jenis tanaman cengkeh (Syzygium aromaticum) dengan INP sebesar $40 \%$. INP terendah pada fase ini terdapat pada jenis tanaman permudaan jenis cempaka (Michelia champaca) dengan INP sebesar $4 \%$.
Ketiga jenis tanaman tersebut diketahui merupakan jenis tanaman yang sangat dibudidayakan oleh masyarakat sekitar dan atau di dalam kawasan hutan, disusul tanaman jenis kopi dan cengkeh. Seperti yang diungkapkan Dinas Koperindag (2011) dalam Prameswita et al.(2014)bahwa Provinsi Lampung memiliki 5 komoditas utama perkebunan yaitu kopi, kakao, lada, kelapa sawit, dan karet.

Pada fase pancang dan fase pohon tanaman jenis durian (Durio zibethinus) memiliki peranan yang paling besar dengan INP pada kedua fase tersebut sebesar $61 \%$ dan $48 \%$. Pada fase tiang, jenis tanaman dengan INP yang lebih besar dimulai dari jenis tanaman durian sebesar $61 \%$, petai (Parkia speciosa) sebesar 55\%, dan melinjo (Gnetum gnemon) sebesar $43 \%$. Adapun jenis tanaman yang memiliki INP terendah pada fase tiang adalah jenis tanaman karet (Hevea brasiliensis) dengan INP sebsar 7\%.

Fase pohon jenis pohon durian memiliki INP tertinggi sebesar $48 \%$, selanjutnya kemiri (Aleurites moluccana) dengan INP sebesar $43 \%$, dan jenis pohon cempaka (Michelia champaca) serta petai yang keduanya memiliki INP sebesar 29\%. Adapun jenis pohon yang memiliki INP paling rendah jenis pohon awar-awar (Ficus septica), jati (Tectona grandis), dan jengkol (Archidendron pauciflorum) dengan INP sebesar 4\%. Tanaman durian merupakan jenis tanaman yang dominan dibudidayakan oleh masyarakat sekitar hutan karena Provinsi Lampung merupakan salah satu provinsi penghasil durian. Terbukti bahwa Provinsi Lampung mampu memproduksi buah durian sekitar 40.000 ton setiap tahunnya (BPS, 2014 dalam Herwanti, 2016). Hal ini juga mengindikasikan bahwa penggarapan telah cukup 
65 / Rendra T, Duryat, dan Bintoro A.

lama terjadi di kawasan hutan register $21 \mathrm{KPH}$ XI

Pesawaran, terlebih lagi pada kawasan blok inti register tersebut.

\section{Kesimpulan}

Berdasarkan hasil penelitian yang telah dilakukan dapat disimpulkan bahwa blok inti hutan lindung register $21 \mathrm{KPH} \mathrm{XI} \mathrm{Pesawaran} \mathrm{diketahui} 40$ jenis tanaman yang tersusun dari fase semai dan tumbuhan, tiang, pancang serta pohon. Adapun 40 jenis tanaman tersebut terdiri dari 21 famili. Tumbuhan bawah dan fase semaimenunjukkan jumlah jenis tanaman yang lebih tinggi jika dibandingkan dengan ketiga fase lainnya. Faktor yang mendukung hal tersebut disebabkan banyaknya ruang terbuka sehingga cahaya secara langsung mengenai tumbuhan bawah. Theobroma cacao adalah jenis tanaman yang memiliki INP tertinggi sebesar $130 \%$ dikarenakan tanaman tersebut dibudidayakan oleh masyarakat sekitar kawasan blok inti hutan lindung register $21 \mathrm{KPH}$ XI Pesawaran.

\section{DAFTAR PUSTAKA}

Cahyanto, T., Chairunnisa, D. and Sudjarwo, T. (2014) 'Analisis vegetasi pohon hutan alam Gunung Manglayang Kabupaten Bandung', Jurnal ISTEK, VIII(2), pp. 145161.

Efendi, M. et al. (2016) 'Komposisi dan keanekaragaman flora di Gunung Pesagi, Sumatera', Prosiding Seminar Masyarakat Biodiversitas Indonesia, 2(2010), pp. 198-207. doi: $10.13057 /$ psnmbi/m020214.

Herwanti, S. (2016) 'Analisis pemasaran durian di Desa Talang Mulya Kabupaten Pesawaran', Jurnal IImiah ESAl, 10(1), pp. 65-70.

Hilwan, I., Mulyana, D. and Pananjung, W. G. (2013) 'Keanekaraaman jenis tumbuhan bawah pada tegakan sengon buto ( Enterolobium cyclocarpum Griseb .) dan trembesi ( Samanea saman Merr .) di lahan pasca tambang batubara PT Kitadin , Embalut , Kutai Kartanagara , Kalimantan Timur', Jurnal Silvikultur Tropika, 4(1), pp. 6-11.

Indriyanto (2008) Ekologi Hutan. 2nd edn. Jakarta: PT. Bumi Aksara.

Kainde, R. P. (2011) 'Analisis Vegetasi Hutan Lindung Gunung Tumpa', Eugenia, 17(3), pp. 1-11.

Mustari (2014) Rencana Pengelolaan Hutan Jangka Panjang (RPHJP) KPHL Pesawaran. 1st edn. Gedong Tataan, Pesawaran, Lampung: Kesatuan Pengelolaan Hutan XI Pesawaran.

Nagel, P. J. F. (2011) 'Pelestarian hutan dalam hubungannya dengan lingkungan dan potensi ekonomi', Proceeding PESAT (Psikologi, Ekonomi, Sastra, Arsitektur \& Sipil), 4(1), pp. 7-13.

Prameswita, W., Ismono, R. H. and Viantimala, B. (2014) 'Faktor-faktor yang mempengaruhi volume ekspor kakao Provinsi Lampung', JIIA, 2(1), pp. 1-7.

Widiyanti, P. and Kusmana, C. (2014) 'Komposisi jenis dan struktur vegetasi pada Kawasan Karst Gunung Cibodas , Kecamatan Ciampea , Kabupaten Bogor', Jurnal Silvikultur Tropika, 5(2), pp. 69-76.

Zulkarnain (2013) 'Analisis penetapan kriteria kawasan hutan', Jurnal AGRIFOR, XII(2), pp. 230-243. 
Analisis Vegetasi ... / 66

--- this page left blank --- 